\title{
SISTEM PEMBIAYAAN LEASING DI PERBANKAN SYARIAH
}

\author{
Dhany Hermawan \\ dhanyhermawan34@gmail.com \\ Fujiah \\ afaazra@yahoo.com \\ (Fakultas Agama Islam, Universitas Muhammadiyah Tangerang)
}

\begin{abstract}
Abstrak;
Artikel ini mencoba mengeksplorasi konsep teoritis penyewaan sebagai produk dari perbankan syariah menunjukkan bagian dari konsep ekonomi Islam. Ekonomi Islam bertujuan untuk mendapatkan nilai dan etika islam. Munculnya lembaga perbankan syariah karena adanya motivasi untuk menghindari system Riba. Larangan sistem bunga dalam Islam merupakan referensi utama dalam aktivitas perbankan syariah. Label syariah menyiratkan beberapa konsekuensi baik dalam konsep atau dalam sistem operasi bank syariah termasuk leasing harus didasarkan pada Al-Qur'an dan Sunnah.
\end{abstract}

\section{Kata kunci: leasing, Perbankan, Syari’ah, Pembiayaan.}

\section{Abstract;}

This article tries to explore the theoretical concept of leasing as a product of Islamic banking showing a part of the Islamic economic concept. Islamic economics aims to obtain Islamic values and ethics. The emergence of Islamic banking institutions is due to the motivation to avoid the Riba system. The prohibition on the interest system in Islam is the main reference in Islamic banking activities. The sharia label implies several consequences either in concept or in the operating system of a syariah bank including leasing to be based on the Qur'an and Sunnah.

Keywords: leasing, banking, syari'ah, financing.

\section{A. Pendahuluan}

Sistem perbankan syariah merupakan bagian dari konsep ekonomi islam yang memiliki tujuan untuk membumikan sistem nilai dan etika islam dalam wilayah dalam ekonomi. Kelahiran lembaga perbankan syariah ${ }^{1}$ didorong oleh adanya desakan kuat dari orang islam yang ingin

\footnotetext{
${ }^{1}$ Secara teoritis, gagasan tentang konsep bank syari'ah pada dasarnya telah muncul sejak tahun 1940-an. Namun demikian pendirinya belum dapat terealisir karena kondisi yang tidak memungkinkan dan belum adanya pemikiran tentang bank Islam yang menyakinkan. Baca Warkum Sumitro. 1996. Asas -asas Perbankan Islam dan lembaga Keuangan Terkait (BM UI dan Takaful di Indonesia). Jakarta: Rajawali Press.h. 8.
}

terhindar dari transaksi bank yang dipandang mengandung unsur riba. Adanya pelanggaran riba dalam islam merupakan peganggan utama bagi bank syariah dalam melaksanakan kegiatan usahanya, sehingga kontrak hutang piutang antara perbankan syariah denga nasabah harus berada dalam koridor bebas bunga. Hingga saat ini perbankan syariah telah menyebar ke berbagai negara, bahkan negara Barat. Di indonesia, pekembangan bank syariah ${ }^{2}$ menunjukan peningkatan

${ }^{2}$ Di Indonesia, bank pertama yang beroprasional dengan prinsip syariah adalah Bank Muamalat Indonesia (disingkat:: BMI). Akte pendiriannya BMI ditandatangani pada tanggal 1 
yang semakin pesat dari tahun ke tahun. Sejak tahun 1992 hingga akhir Desember 2006, sedikitnya terdapat 3 (tiga) bank umum syariah dan 20 (duapuluh) Unit Usaha Syariah.

Adanya label 'syriah' pada lembaga tersebut, memiliki konsekuensi pada oprasionalnya harus selalu melaksanakannya prinsip-prinsip syariah dalam seluruh produk dan oprasionalnya yang bersumber dari al-Qur'an maupun sunnah Rasulallah SAW. Namun karena kedua sumber tersebut mengatur hal-hal yang bersifat umum, maka dibutuhkan 'ijtihad' untuk mengatur hal-hal yang bersifat khusus. Jika tidak maka akan menimbulkan permasalahan alam pelembagaan atau sistemisasi lembaga keuangan tersebut, sehingga sisteminasi lembaga perbankan yang saat ini berada dalam lingkungan sistem konvensional yang nota bene-nya sekular tidak akan dapat sesuai dengan ketentuan syariat Islam. Hal yang demikian akan menjadi posisi perbankan syariah yang hingga kini masih tetap merupakan sub sistem dari sistem moneter tidak dapat melepaskan dari praktik riba. Sebagaimana bank

November 1991, dan mulai beroperasi pada tanggal 1 Mei 1992. Pada awal pendirinya, keberadaan BMI belum mendapat perhatian yang optimal dalam sistem perbankan nasional, karena landasan hukum operasionalnya yang menggunakan sistem syari'ah hanya dikategorikan sebagai "bank dengan sistem bagi hasil" tanpa ada rincian yang jelas mengenai landasan hukum syari'ah dan jenis-jenis usahanya. Dengan disahkannya Undang-undang perbankan NO. 10 tahun 1998 tentang perubahan Undang-undang No. 7 tahun 1992 yang diikuti dengan dikeluarkannya sejumlahketentuan pelaksanaan dalam bentuk Surat Keputusan (SK) Direksi Bank Indonesia, telah memberikan landasan hukum yang lebih kuat dan luas bagi berdirinya perbankan syariah di Indonesia. Undang-undang ini dapat dijadikan landasan hukum yang kuat baik dari segi kelembagaan maupun landasan operasional syariahnya, sehingga dengan perundang-undangan ini memberikan kesempatan yang luas untuk pengembangan jaringan perbankan syariah. konvensional, bank syariah memiliki fungsi sebagai intermediasi yang menjembatani para penabung dan investor. Hubungan antara bank syariah dengan nasabah lebih bersifat partner dari pada lender atau borrower, sehinga bank ini dapat bertindak sebagai pembeli, penjual atau pihak yang menyewakan. Produk yang ditawarkan bank syariah sangat bervariasi dengan prinsip saling menguntungkan (fainess) dan menjunjung tinggi prinsip-prinsip keadilan. Produk yang ditawarkan bank syariah berupa pengerahan dana masyarakat, penyaluran dan jasa perbakan lainnya. ${ }^{3}$ Produk pengerahan dana masyarakat diwujudkan alam simpanan giro, deposito, tabungan giro wadi'ah, deposito mudharabah dan tabungan mudharabah. produk penyaluran dana kepada masyarakat dilakukan dalam bentuk produk kredit mudharabah, kredit mudharabah, kredit bai bittaman ajil, kredit al qardhul hasan dan musyarakah. Produk jasa perbankan lainnya seperti jual beli valuta asing, bank garansi, jasa penerbitan L/C, deposito box, dan jasa transfer.

Pembiayaannya diberikan dalam rangka meningkatkan kesempatan kerja nasabah dan kesejahteraan ekonomi mereka sesuai ketentuan dan nilai Islam. ${ }^{4}$ Menurut Ataul Haque sebagaimana dikutip syafii Antonio, mekanisme produk bank syariah sebagai berikut: ${ }^{5}$

1. Mudharabah (profit loss sharing), yaitu kerjasama antara bank (shahibul mal) dengan nasabah (mudharib). Shohibul mal memberikan $100 \%$ dan

${ }^{3}$ Baca dalam Ahmad Ramzy Tadjoeddin dkk. 1992. Berbagai Aspek Ekonomi Islam. Yogyakarta: Tiaca Wacana dan P3EI UII.h. 167170.

${ }^{4}$ Achyar Ilyas, Stategi Investasi Perbankan Syariah, dalam Modal, No 17, II Maret 2004, h. 20.

${ }^{5}$ Baca lebih lanjut Syafi'i Antonio. 2001. Bank Syari'ah dari Teori Ke Praktek. Jakarta: Gema Insan Press. 
kepada mudharib yang akan dikembalikannya beserta porsi keuntungan yang telah disetujui sebelumnya. Bila terjadi kerugian maka seluruh kerugian dipikul oleh shahibul mal, dan mudharib kehilangan keuntungan (imbalan bagi hasil) atas kerja yang dilakukan.

2. Musyarakah, yaitu suatu perkongsian antara dua pihak atau lebih dalam suatu proyek, di mana masing-masing pihak berhak atas segala keuntungan dan bertanggungjawab akan segala kerugian yang terjadi sesuai dengan penyertaan masing-masing.

3. Ijarah (sewa), yaitu memberikan kesempatan kepada penyewa untuk mengambil pemanfaatan dari barang sewaan untuk jangka waktu tertentu dengan imbalan yang besarnya telah disepakati bersama.

4. Bai as-salam, yaitu proses jual beli yang pembayarannya dilakukan sekarang sedang penyerahan barangnya dilakukan pada masa yang akan datang.

5. Bai murabahah, yaitu akad jaul beli barang. Termasuk dalam kategori ini adalah bai' bi thaman ajil (mark up), yaitu menjual dengan harga asal ditambah dengan margin keuntungan yang telah disepakati dan dibayar secara kredit.

6. Wadi'ah, yaitu sistem titipan murni dari satu pihak kepada pihak lain yang harus dijaga dan dikembalikan kapan saja.

7. Rahn (gadai), yaitu menjadikan barang yang mempunyai nilai harta menurut pandangan syariah sebagai jaminan utang, sehingga orang yang bersangkutan boleh mengambil utang semua atau sebagian.

8. Wakalah, yaitu akad pelimpahan kekuasaan oleh seorang sebagai pihak pertama kepada orang lain sebagai pihak kedua dalam hal-hal yang diwakilkan.
9. Hiwalah, yang memindahkan utang dari tangungan orang yang berutang menjadi tanggungan orang yang membayar utang.

10. Kafalah, yaitu jaminan yang diberikan oleh penanggung kepada pihak ketiga untuk memenuhi kewajiban pihak kedua atau yang ditanggung.

Dari produk-produk ersebut, bank syariah dapat meningkatkan investasinya terutama dalam bentuk pembiayaan atas kegiatan usaha produksi, distribusi, jual beli dan konsumsi dari produk atau jasanya kepada nasabah debiturnya secara baik dan signifikan. Pembiayaan yang diberikan juga dilakukan atas dasar manfaat yang dapat mendorong terciptanya sistem ekonomi dan kegiatan usaha yang berkeadilan dengan menerapkan kaidah moral dan tata nilai yang mengarahkan tercapainya kemaslahatan orang banyak. ${ }^{6}$ Pola utama pembiayaan yang diberikan kepada nasabah dapat berupa mudharabah dan musyarakah. model ini lebih bersifat equity dan beresiko tinggi karena rate of retrun-nya tidak ditetapkan di awal dan nilai nominalnya bersifat kondisional. Adapun pembiayaan sekundernya dilakukan dengan berlandaskan perinsip jual beli, sperti murabahah, salam, ijarah, dan ijarah wa iqtina. Pola pembiayaan ini lebih berdasar kredit dan tidak beresiko tinggi, karena rate return-nya ditetapkan di awal perjanjian. Namun demikian pola pembiayaan model kedua ini sering menimbulkan praktek perkreditan berbasis bunga. Dari berbagai fasilitas pembiayaan tersebut, pembiayaan ijarah dianggap memiliki kesamaan dengan leasing

\footnotetext{
${ }^{6}$ Menurut Umar Chapra, Pembiayaan bank syariah harus diarahkan untuk membentuk lapangan kerja dan kesejahteraan ekonomi masyarakat secara luas. Baca lebih lanjut, Umar Chapra. 2001. The Future of Economics: an Islamic Perspective. Terj. Amdiar Amir dkk. Jakarta: Shariah Economics and Banking Institute.
} 
sebagaimana dikenal dalam sistem ekonomi konvensional.

\section{B. Mengenal Sistem Pembiayaan Leasing}

Istilah leasing memiliki pengertian beranekaragam dan bervariasi, namun secara umum leasing berarti equipment funding, yaitu pembiayaan peralatan/barang modal untuk digunakan pada proses produksi suatu perusahaan baik secara langsung maupun tidak langsung. Leasing juga berarti pembiayaan perusahaan dalam bentuk penyedian barang modal dengan pembayaran secara berkala oleh perusahaan yang menggunakan barang modal tersebut, dan dapat membeli atau memperpanjang jangka waktu berdasarkan nilai sisa. ${ }^{7}$ Perjanjian leasing tidak hanya sebatas suatu kontrak atau persetujuan sewa yang obyeknya berupa barang modal, dan pihak lessee memiliki hak opsi dengan harga berdasarkan nilai sisa, namun lebih kompleks, karena dalam leasing dapat timbul hak beli, dan hal ini sangat mendekati transaksi jual beli aktiva angsuran dan dapat pula seperti sewa menyewa biasa.

Leasing memiliki sejarah yang cukup panjang. Meskipun tidak diketahui secara pasti, namun diyakini kegiatan transaksi leasing ini telah terjadi sejak tahun 2000 SM yang dilakukan oleh orang-orang Sumeria. ${ }^{8}$ sesuai dengan dokumen, pada awalnya transaksi leasing dilakukan oleh orang-orang Sumeria yang dimulai dari peralatan pertanian, hak-hak penggunaan tanah dan air sampai binatang ternak. Pada awalnya leasing merupakan usaha pembiayaan peralatan, pertanahan dan

\footnotetext{
${ }^{7}$ Ainun Naim. 1992. Akuntansi Keuangan 2. Yogyakarta: BPFE.h. 150

${ }^{8}$ Tom Clark. 1985. The Wordo of Leasing, dalam Leasing Finance. London: Euromoney Publications.h. 1 .
}

pertenakan. Seiring dengan perkembangan industri, manufaktur dan transportasi menjadikan bertambahnya obyek leasing di inggris. Di samping di inggris, praktek pembiayaan dengan menggunakan leasing di Amerika juga telah mulai dikenal sejak tahun 1970-an. Praktek leasing di Amerika tumbuh dengan pesatnya setelah adanya pembangunan rel kereta api, yang rata-rata pembiayaannya dilakukan dengan cara leasing. Selanjutnya kegiatan usaha leasing menyebar ke berbagai negara dengan pesatnya setelah tahun 1950-an, khususnya di Eropa dan Amerika.

Leasing diperkenalkan $\mathrm{d}$ indonesia untuk kali pertama pada tahun 1974 dengan dikeluarkannya Surat Keputusan Bersama Menteri Keuangan, Menteri Perdagangan dan Menteri Perindustrian No. Kep.122/MK/2/974 dan No. 30/Kpb/I/974 tanggal 7 februari 1974 tentang "Perizinan Usaha Leasing". 9 Pada dekade 80 -an perusahaan leasing semakin bertambah banyak sejalan dengan itu volume transaksinya mengalami kenaikan dari tahun ke tahun. Dalam masa perkembangannya, leasing dikenal sebagai salah satu jalan atau cara untuk memperoleh modal bagi perusahaan yang tidak memiliki modal. ${ }^{10}$ Di samping tidak cukup modal, juga kurang mampu membayar bunga, jika modal yang diperlukan berasal dari kredit. Bagi sebagian masyarakat indonesia berpandang bahwa pembiayaan leasing identik dengan jual beli angsuran dalam bentuk sewa beli. ${ }^{11}$ Hal ini dapat dimengerti, karena

9 Y,Sri susilo. 2000. Bank dan Lembaga Keuangan Lain. Jakarta: Salemba Empat.h. 129.

${ }^{10}$ Tom Clark, The..... Loc. Cit.

${ }^{11}$ Sebagian masyarakatyang menganggap leasing sebagai pembiayaan peralatan/ barang modal untuk digunakan pada proses produksi suatu perusahaan, baik secara langsung maupun tidak langsung. Dengan demikian pada hakikatnya leasing merupakan salah satu cara pembiayaan yang mirip dengan kredit bank. Perbedaan antara 
dalam perjanjian "leasing" memuat klausula "hal opsi" bentuk hak opsinya adalah "opsi beli" atau opsi perpanjang waktu. pada klausula opsi beli, memberi hak kepada lesse untuk membeli barangbarang modal yang menjadi obyek leasing setelah sampai pada waktu yang dijanjikan. Sedang pada opsi perpanjang waktu, memberi hak kepada lesse untuk memperpajang waktu leasing dari batas jangka waktu perjanjian. ${ }^{12}$ Dengan mengaitkan leasing dengan opsi beli, perjanjian leasing memiliki beli angsuran, apabila dalam perjanjian tercantum "buy decision".

Perjanjian leasing secara umum memiliki dua bentuk, yaitu: operating lease dan finance lease. ${ }^{13}$ Dalam perkembangan selanjutnya klasifikasi leasing menjadi bermacam-macam dan sangat variatif. Ditinjau dari aspek jenis transaksinya, tehnik pembiayaan leasing secara garis besar dapat dikelompokkan empat, yaitu: operating lease, finansial lease, leveraged lease dan sales tpe lease. Tehnik pembiayaan jenis operating lease, lessor membeli barang modal dan disewagunakan kepada lesse. Pembayaran periodik yang dilakukan lessee tidak mencakup biaya yang dikeluarkan lessor untuk mendapatkan barang modal dan bunganya. Lessor hanya mengharapkan keuntungan dari penjualan barang-barang modalyang disewagunakan dan sumber

keduanya hanya terletak pada bentuk barang yang diberikan, leasing memberikan bantuan dalam bentuk barang modal sedangkan bank memberikan bantuan berupa permodalan. Richard Button Simatupang. 1996. Aspek Hukum dalam Bisnis. Jakarta: Rineka Cipta. Hlm. 134.

${ }^{12}$ M. Yahya Harapah.1991. Leasing dan Surat-surat Berharga Serta Kaitannya dengan sangketa Harta Bersama dan Waris di Pengadilan Agama, dalam Mimbar Hukum, No 3 Thn II, 1991, h. 43 .

${ }^{13}$ John D. Martin, et. al. 1994. Dasar-dasar Managemen Keuangan. Terj. Haris Munandar. Jakarta: Raja Grafindo Persada.h. 217. penghasilan dari perjanjian leasing yang lain, oleh karenanya perlu keahlian khusus memasarkan kembali asset tersebut. ${ }^{14}$ Semua pembayaran pajak, asuransi dan pemeliharaan barang/asset yang dileasekan menjadi tanggung jawab lessor. Dalam operating lease, lessee boleh menunda atau membatalkan pembayaran asalkan sejak awal ia memberitahu kepada lessor. Dengan demikian bentuk ini dapat dikategorikan sebagai sumber pembiayaan jangka pendek. Jenis ini memiliki ciri-ciri: (1) waktunya relatif singkat jika dibandingkan dengan umur barang obyek leasing, (2) tersedianya secara khusus service termasuk pemeliharaan, (3) hak atau kebebasan untuk membatalkan leasing hanya dibenarkan dalam alasan-alasan yang sangat terbatas serkali, dan (4) segala resiko kerusakan yang timbul, pemeliharaan dan service menjadi tanggung jawab lessor. Dari keempat ciri tersebut menunjukan bahwa dalam operating lease tidak ada tujuan untuk membebani lessee untuk membayar sewa cicilan kepada lessor sebesar jumlah harga modal yang ditanamkannya kepada obyek leasing. ${ }^{15}$ Jenis ini disebut juga non full pay out lease.

Dalam tehnik pembiayaan jenis financial lease, perusahaan leasing sebagai lessor adalah pihak yang membiayai penyediaan barang modal, sedangkan lessee hanya melakukan pemesanan, pemeriksaan dan pemeliharaan barang modal yang menjadi obyek transaksi leasing. Selama masa leasing inilah, lesse melakukan pembayaran sewa secara berkala di mana jumlah seluruhnya ditambah dengan pembayaran sisa residu. ${ }^{16}$

${ }^{14}$ IAI, Prinsip Akuntansi Indonesia. 1984. Standar Khusus Akuntansi Sewa Guna Usaha. Jakarta: Rineka Cipta.h. 246.

${ }^{15}$ M. Yahya Harahap. Leasing....Op. Cit., h. 246.

16 IAI. Prinsip Akuntansi Indonesia. Standar.... Op Cit., h. 246. 
Dalam financial leasing termuat ketentuan kontraktual bahwa pihak lessee tidak boleh menunda atau membatalkan serangkai pembayaran kepada lessor sebagai imbalan atas pemanfaatan aktiva. Tehnik ini sering disebut sebagai full pay out lease, yaitu suatu bentuk pembiayaan dengan cara kontrak antara lessor dengan lessee. Kontrak ini mencakup, antara lain: (1) obyek leasing dapat berupa barang yang bergerak maupun yang tidak bergerak yang memiliki umur maksimum sama dengan masa kegunaan ekonomis barang tersebut; (2) pembayaran priodik kepada lessor merupakan angsuran yang meliputi alokasi untuk biaya perolehan ditambah dengan semua biaya lainnya yang dikeluarkan lessor serta tingkat keuntungan yang diharapkan; (3) tidak boleh ada pembatalan secara sepihak untuk mengakhiri perjanjian leasing selama jangka waktu yang disetujui; (4) resiko ekonomis termasuk juga biaya pemeliharaan dan biaya lainnya yang berhubungan dengan barang ditanggung oleh lessee; (5) lessee pada akhir kontrak memiliki hak opsi untuk membeli barang sesuai dengan nilai sisa yang disepakati atau mengembalikan pada lessor atau memperpanjang lease sesuai dengan syarat-syarat yang telah disepakati bersama.

Transaksi leasing jenis laveraget lease melibatkan sekurang-kurangnya tiga pihak, yaitu penyewa guna usaha, perusahaan leasing dan kreditor jangka panjang yang membiayai bagian terbesar dari transaksi leasing. ${ }^{18}$ Jenis ini juga dikenal sebagai third party leases atau investor leases. Dalam transaksi jenis ini, pihak yang meminjamkan akan menerima uang jasa karena mengatur pinjaman

\footnotetext{
${ }^{17}$ Y. Sri Susilo. Et. al., Bank.... Op. Cit., h. $132-134$

${ }^{18}$ Amin Wijaya Tunggal dan Arif Djohan Tunggal. 1995. Akuntansi Leasing (sewa Guna Usaha). Jakarta: Rineka Cipta.h.110.
}

tersebut, di samping juga pendapatan bunga. ${ }^{19}$ Jenis ini sering digunakan pada transaksi besar pada barang modal bernilai tinggi dengan penyewa yang tidak mampu untuk mengambil keuntungan pajak atas investasi atau penyusutan yang dipercepat. Adapun leasing jenis sales type lease merupakan transaksi pembiayaan leasing secara langsung (direct finance lease) di mana dalam jumlah transaksi termasuk laba yang diperhitungkan oleh penyalur yang juga merupakan perusahaan leasing. Leasing jenis ini seringkali merupakan suatu jalur pemasaran bagi produk perusahaan tertentu. ${ }^{20}$

Ditinjau dari pihak lessor, kontrak leasing dapat diklasifikasikan menjadi lease kapital dan lease operasi. Lease kapital adalah kontrak lease yang memberikan penyewa hak untuk menggunakan manfaat aktiva yang disewa secara material meliputi bagian yang lebih besar dari manfaat keseluruhan aktiva, atau penyewa mempunyai kesempatan yang besar untuk memiliki aktiva yang disewa sehingga mengakibatkan pihak penyewa dapat mengakui adanya aktiva lease. Adapun lease operasi adalah kontrak lease yang memberikan penyewa hak menggunakan aktiva dalam priode tertentu yang tidak mencakup lebih besar manfaat aktiva yang bersangkutan sehingga penyewa tidak dapat mengakui adanya aktiva lease. kontrak lease kapital tejadi apabila memenuhi syarat-syarat tertentu, yaitu; (1) Kontrak lease mengakibatkan adanya pemindahan hak milik aktiva; (2) Kontrak lease memuat adanya hak membeli aktiva; (3) Jangka waktu lease sama dengan $75 \%$ atau lebih dari taksiran umur ekonomis aktiva yang disewa dan

\footnotetext{
${ }^{19}$ Edward W. Reed dan Edward K. Gill. 1995. Bank Umum. Terj. ST. Dianjung. Jakarta: Bumi Aksara.h. 260.

${ }^{20}$ Amin Wijaya Tunggal, dan Arif Djohan Tunggal. Akuntansi... Op. Cit., h. 109.
} 
permulaan masa lease tidak jatuh pada saat umur aktiva tersebut 25\%; dan (4) Nilai sekarang dari pembayaran lease minimum adalah sama dengan $90 \%$ atau lebih dari harga pasar yang wajar aktiva. ${ }^{21}$

Ditinjau dari segi persektif kepentingan lessee, suatu lessee dapat dikategorikan sebagai capital lease dan operating lease. ${ }^{22}$ suatu lease dapat diklasifikasikan sebagai capital lease apabila lease agrement-nya dapat memenuhi salah satu kriteria: (1) pengalihan pemilikan atas property kepada lessee dilaksanakan pada saat berakhirnya perjanjian lease, (2) mencantumkan pilihan untuk membeli property dengan harga yang murah, (3) perjanjian lease sama dengan $75 \%$ atau lebih dari estimated economic life, dan (4) present value dari harga sewa dan pembayaran lease lainnya sama dengan $90 \%$ atau lebih dari properti yang di-lease-kan dikurang kredit pajak investasi yang ditahan oleh lessor. Apabila tidak memenuhi salah satu syarat tersebut, maka lease dikategorikan sebagai operating lease. $^{23}$

Ditinjau dari teknis pelaksanaannya, transaksi leasing dapat dilaksanakan melalui dua cara, yaitu direct leasing dan sale and lease back. Dalam transaksi jenis direct leasing, penyewa guna usaha belum pernah memiliki barang modal/aset yang menjadi subyek leasing sehingga atas permintaannya perusahaan leasing membeli barang tersebut. Tujuan utama penyewa guna usaha dalam jenis ini adalah

\footnotetext{
${ }^{21}$ Ainun Naim. Akuntansi... Op. Cit., h. 153154.

${ }^{22}$ Bagi lessee, pengkategorian ini sangat berpengaruh dalam sistem akuntansinya, sebab capital lease masuk dalam perhitungan neraca (on balance sheet), sedangkan operating lease tidak masuk dalam perhitungan neraca (off balance sheet). Lihat lebih lanjut Rudy Tri Santono. 1996. Mengenal Dunia Perbankan. Yogyakarta: Andi Offset. h. 31 31.
}

mendapatkan pembiayaan melalui leasing untuk memperoleh barang modal yang dapat digunakan dalam proses produksi. Adapun dalam transaksi sale and lease back sudah dimilikinya kepada perusahaan leasing dan atas barang modal yang sama tersebut,kemudian dilakukan kontrak leasing antara penyewa guna usaha (lessee) dengan perusahaan leasing (lessor). ${ }^{24}$ Motif yang mendasari terjadinya transaksi bentuk ini terletak pada kebutuhan modal kerja. Jenis transaksi Sale and lease back dapat dibedakan menjadi dua, yaitu technical sales and lease back, dan true sales and lease back. ${ }^{25}$

Di samping kedua jenis tersebut, dikenal juga jenis syndication lease, yaitu bentuk transaksi di mana lessor tidak ingin mengambil resiko atas seluruh transaksi, sehingga berbagi resiko dengan sesama lessor untuk transaksi yang sama. Agar tidak membingungkan lessee, salah satu lessor akan menjadi lead syndicato sehingga komplikasi transaksi dengan beberapa lessor tidak membingungkan lessee. Selain itu, lessor dan lessee dapat juga melakukan direct finance lease dengan kerjasama, yaitu lessor bersamasama membiayai lessee, dengan cacatan setiap lessor dan lessee membuat perjanjian sendiri dengan obyek yang berbeda, namun syarat dan pembiayaan harus sama untuk tujuan membagi resiko antar lessor. $^{26} \mathrm{Di}$ samping itu, leasing sebagai sebuah perjanjian kontrak mengandung ciri-ciri, yaitu: (1) hubungan kontrak paling sedikit antara dua pihak yang menghendaki pemanfaatan obyek lease tanpa menjadi pemilik menurut hukum, (2) menyangkut barang khusus yang merupakan suatu kesatuan tersendiri,

${ }^{24}$ Amin Wijaya Tunggal, et. al... Akuntansi... Op. Cit., h. 110

${ }^{25}$ Lihat lebih lanjut Budi Rachmat. Multi...Op. Cit., h. 34.

${ }^{26}$ Budi Rachmat. Multi... Ibid., h. 39. 
(3) memperoleh pemakaian merupakan tujuan utama yang berupa memberikan kepada leassee hak pemakaian atas barang tertentu selama waktu yang telah ditetapkan, dan (4) selalu terdapat hubungan antara lamanya kontrak dengan lamanya pemakaian barang yang merupakan obyek lease. ${ }^{27}$

\section{Leasing dan Ijarah: Titik Persinggungan \\ Ijarah adalah akad sewa menyewa} antara muajjir (lessor) dengan musta'jir (lessee) atas ma'jur (obyek sewa) untuk mendapatkan imbalan atas barang yang disewakan. Dalam teknik operasional perbankan makai ijarah berarti adanya pemindahan manfaat suatu barang. Ijarah sebenarnya menyerupai jual beli, hanya saja apabila jual beli yang menjadi obyek transaksi adalah barang sedang ijarah adalah jasa. Pada masa akhir kontrak sewa, bank dapat saja memberikan pilihan kepada penyewa untuk memiliki barang yang disewakan kepada penyewa, apabila ini terjadi maka akad sewanya disebut sebagai ijarah al muntahina bit-tamlik (sewa menyewa yang diikuti dengan perpindahan kepemilikan obyek sewa) atau dalam model konvensional dikenal dengan istilah financing lease. Sebagai bentuk pembiayaan yang memiliki kemiripan dengan ijarah, leasing merupakan suatu perjanjian antara pemilik barang (lessor) dengan pemakaian barang (lessee). Pihak lessee berkewajian membayar sewa secara periodik kepada lessor sebagai kompensasi atas penggunaan barang. Perjanjian atau kontrak leasing pada umumnya dilakukan secara tertulis dan memuat berbagai persyaratan termasuk kondisi dan persyaratan transaksi leasing. Persyaratanpersyaratan dalam perjanjian tersebut memuat jangka waktu penggunaan barang,

${ }^{27}$ Komar Andasasmita. 1989. Serba Serbi Leasing. Bandung: INI. h. 37-41. jumlah dan cara pelaksanaan angsuran, spesifikasi barang yang di lease dan persyaratan pengalihan pada akhir masa kontrak. Sebagai sebuah transaksi yang sering dianggap sewa menyewa, leasing, terutama financial lease, merupakan suatu bentuk perjanjian kontrak yang memiliki salah satu sifat noncancelable bagi pihak lessee. Perjanjian kontrak tersebut menyatakan bahwa lessee bersedia atas pengguna suatu aset yang menjadi obyek lease. Sedangkan di pihak lessee, ia berhak untuk mendapatkan manfaat ekonomis dengan mempergunakan barang aset yang disewakan, sedang hak kepemilikan tetap berada pada pihak lessor ${ }^{28}$ kecuali pihak lessee menghendaki untuk membeli barang aset dengan cara membelinya di akhir kontrak.

Antara ijarah dalam islam dengan leasing memiliki kesamaan, oleh karena itu tidak mengherankan jika sebagian pemikir islam modern menjadikan istilah ijarah dengan operating lease sebagai istilah yang tidak ada bedanya sama sekali. ${ }^{29}$ Lebih dari itu bentuk ijarah al muntahina bi-tamlik sering disamakan juga dengan financial lease with purchase option. Antara leasing dan sewa menyewa, merupakan suatu perjanjian antara dua belah pihak, dimana pihak yang satu mengikatkan diri untuk memberikan kepada pihak yang lainnya suatu hak untuk menggunakan atau menikmati suatu barang selama jangka waktu tertentu dengan pembayaran yang telah disepakati bersama.

Disamping itu, antara leasing dan sewa menyewa sama-sama sebagai bentuk transaksi untuk mengambil manfaat tanpa harus memiliki barang aset dengan memberikan sejumlah uang sewa, baik di

${ }^{28}$ Amin Widjaya Tunggal, dan Arief Djohan Tunggal. 1994. Aspek Yuridis dalam Leasing. Jakarta: Rineka Cipta. h.25.

${ }^{29}$ Muhammad. 2001. Sistem dan Prosedur Operasional Bnak Syariah. Yogyakarta: UII Press. Cet. Ke-II, h.35. 
awal maupun di akhir kontrak. Uang sewa dalam leasing maupun dalam sewa menyewa merupakan bentuk imbalan jasa dari penyewa (lessee) kepada pemilik barang (lessor) karena penggunaan manfaat barang yang disewakan. Apalagi kita amati secara seksama keduanya samasama berdasarkan pada azas kebebasan berkontrak yang menjadikan leasing sebagai bentuk khusus perjanjian sewa menyewa. Terlebih lagi keduanya merupakan bentuk perjanjian konsensuil, di mana perjanjian tersebut sudah sah dan mengikat ketika terjadi kata sepakat antara kedua pihak.

Perbedaan prinsipil $^{30}$ antara leasing dengan sewa menyewa terletak pada tidak adanya option right atau hak pilih bagi penyewa dalam sewa menyewa untuk membeli barang yang disewakan tersebut. Unsur terpenting dalam perjanjian sewa menyewa adalah kenikmatan dari sesuatu barang yang disewakan dan harga sewa, namun dalam prakteknya dalam perjanjian sewa menyewa dapat juga dicantumkan ketentuan-ketentuan khusus yang memberikan hak kepada penyewa suatu opsi, yaitu untuk melanjutkan sewa menyewa atau membeli barang yang disewakan pada saat jangka waktu sewa menyewa berakhir. Adapun perbedaan pokok antara leasing dengan sewa menyewa munurut KUH perdata adalah: ${ }^{31}$

1. Leasing merupakan bentuk metode pembiayaan, sedangkan sewa menyewa belum tentu merupakan bentuk pembiayaan;

2. Obyek perjanjian leasing adalah barang-barang modal atau alat-alat produksi, sedangkan dalam perjanjian sewa menyewa obyeknya juga dapat

\footnotetext{
${ }^{30}$ Dahlan Siamat. 1995. Managemen Lembaga Keuangan. Jakarta: Intermedia.h.156.

${ }^{31}$ Amin Widjaya Tunggal, dan Arief Djohan Tunggal. Aspek... Op. Cit., h. 18.
}

meliputi barang-barang untuk dapat digunakan di luar perusahaan;

3. Subyek dalam leasing ditentukan, yaitu perusahaan yang telah memperoleh izin, sedang dalam sewa menyewa tidak;

4. Jangka waktu leasing merupakan jangka waktu yang tertentu, sedangkan dalam perjanjian sewa menyewa jangka waktunya mungkin bisa tidak terbatas;

5. Jaminan yang harus diberikan oleh seorang yang menyewakan dalam perjanjian sewa menyewa, tidak berlaku sepenuhnya dalam leasing;

6. Imbalan jasa yang dibayar pada perjanjian sewa menyewa adalah uang sewa, sedangkan dalam leasing, lessor berkepentingan memperoleh imbalan uang sewa yang pokoknya merupakan tebusan berkala harga perolehan barang ditambah ongkos pembiayaan, serta lessee tetap berkewajiban membayar seluruh jumlah imbalan jasa tersebut dan harus mengembalikan barang yang di-lease;

7. Dalam sewa menyewa, penyewa ikut memikul resiko obyek sewa menyewa, sedangkan dalam leasing seluruh resiko obyek dan pemeliharaan manjadi tanggung jawab lessee tanpa melibatkanh pihak lessor;

8. Dalam perjanjian sewa menyewa, pihak yang menyewakan telah memiliki atau menguasai barangbarang hendak dipergunakan oleh pihak yang lain dengan membayar uang sewa sebagai imbalan, sedangkan dalam leasing, lessor adalah instansi panyediaan dana (financiers) dan bukan pemilik barang yang biasa disewakan.

\section{Tehnik Pembiayaan Leasing di Bank Syariah}

Secara teoritas proses transaksi leasing terdiri atas tiga tahap, yaitu tahap 
pra-periode leasing, tahap periode leasing, dan tahap pasca periode leasing. Tahap pra-periode leasing diawali dengan adanya kebutuhan lessee yang membutuhkan barang modal serta pembiayaan. Pihak lessee akan menghubungi dan merundingkan kebutuhannya dengan calon supplier dan calon penyedia dana (lessor). Pada tahap periode leasing, lessor sebagai pemilik barang modal memantau transaksi leasing untuk memenuhi apakah lessee telah memenuhi segala kewajibannya sesuai dengan perjanjian leasing. Penyimpangan oleh lessee dalam memenuhi kewajibannya dapat mengakibatkan lessee kehilangan haknya dan menanggung segala resiko yang ditimbulkannya. Sedangkan tahap pasca periode leasing, setelah lessee memenuhi segala kewajibannya kapada lessor termasuk seluruh pembiayaan lease, maka lessee dapat menggunakan hak pilih yang diberikan kepadanya untuk membeli barang modal yang disewakan atau memperpanjang perjanjian leasing.

Adapun teknik yang sering dipergunakan dalam proses pembiayaan leasing dapat dilihat dari jenis transaksi, yang secara garis besar dibagi menjadi dua kategori, yaitu finance lease dan operating lease, perusahan leasing sebagai lessor adalah sebagai pihak membiayai penyediaan barang modal, ${ }^{32}$ sedangkan pada operaing lease, lessor sengaja membeli barang modal dan selanjutnya dilease-kan. Berbeda dengan finance lease, dalam operating lease jumlah seluruh pembayaran berkala tidak mencakup jumlah biaya yang dikeluarkan untuk memperoleh barang modal berikut dengan bunganya. Karena dalam sistem leasing belum dapat terbebas dari bunga, maka bank syariah memberikan pembiayaan sewa dan jual beli tidak menggunakan

$\begin{array}{ccc}{ }^{32} \text { IAI. } & \text { Prinsip } & \text { Akuntansi } \\ \text { Standar...Op.Cit., h. 246. } & \end{array}$

istilah leasing, namun ijarah muntahia bittamlik. ${ }^{33}$ ijarah muntahia bit-tamlik adalah akad sewa menyewa antara pemilik obyek sewa dan penyewa untuk mendapatkan imbalan atas obyek sewa yang disewakannya dengan opsi perpindahan hak milik obyek sewa pada saat tertentu sesuai dengan akad sewa. Selain usaha tersebut juga memperaktekkan salah satu jenis ijarah dalam sistem pembiayaan, yaitu: ijarah mutlaqah, bai at takjiri dan musyarakah mutanasiqah. ${ }^{34}$ Ijarah mutlaqah adalah proses sewa menyewa yang biasa kita temui dalam kegiatan perekonomian sehari-hari. Bai' at takjiri adalah suatu kontrak sewa yang diakhiri dengan penjualan. Dalam kontrak ini pembayaran sewa telah diperhitungkan sedemikian rupa sehingga sebagian merupakan pembelian barang secara berangsur (hire purchase). Musyarakah mutanasiqah merupakan kombinasi antara musyarakah dengan ijarah. ${ }^{35}$ Bahkan bank syariah dapat juga memberikan fasilitas sewa kepada nasabahnya untuk penggunaan satu jenis barang tertentu dengan cara: (1) pada awalnya bank membeli ase yang dibutuhkan nasabah, (2) bank menyewakan aset tersebut kepada nasabah untuk jangka waktu tertentu, dan (3) tarif sewa dan persyaratan lainnya harus telah disepakati terlebih dahulu oleh kedua belah pihak (Atmadja). ${ }^{36}$

\footnotetext{
${ }^{33} \mathrm{Hal}$ ini karena lebih sederhana dalam pembukaan dan bank tidak terlalu direpotkan untuk mengurusi pemeliharaan aset, baik pada saat berlangsung maupun sesudahnya. Syafi'i Antonio. 2001. Bank... Op. Cit. Jakarta: Gema Insani Press.h. 118.

${ }^{34}$ Muhammad Sistem... Op. Cit., h. 35-36.
${ }^{35}$ Muhammad Sistem....Ibid.
${ }^{36}$ Pada pembiayaan pengadaan barang

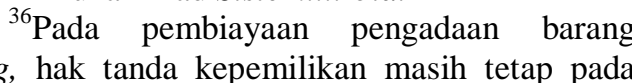
leasing, hak tanda kepemilikan masih tetap pada
bank atau penyediaan dana sampai dijual kepada nasabah setelah habis masa kontrak. Karena Perwata Atmadja, \& Muhammad Syafi'i Antonio. Apa... Op. Cit.h. 28-29.
} 
Apabila mengikuti ketentuan sebagaimana diatur dalam standart akuntansi perbankan syaraiah PSAK 59 sebagaimana dikutip Faqih Nabhan, ${ }^{37}$ maka ketentuan ijarah dan ijarah al muntahia bit-tamlik sebagai berikut:

1. Obyek sewa diakui sebesar biaya prolehan pada saat perolehan dan disusutkan sesuai dengan kebijakan penyusutan pemilik obyek sewa untuk aktva sejenis jika merupakan ransaksi ijarah, dan masa sewa jika merupakan transaksi ijarah muntahia bit-tamlik.

2. Pendapatan ijarah dan ijarah mutahia bit-tamlik diakui selama masa akad secara proporsional kecuali pendapatan ijarah muntahia bit-tamlik melalui penjualan secara bertahap maka besar pendapat setiap periode akan menurun secara progresif selama masa akad karena adanya perluasan bagian perbagian oyek sewa pada setiap periode.

3. Piutang pendapatan ijarah dan ijarah muntahia bit-tamlik diukur sebesar nilai bersih yang dapat direalisasikan pada akhir periode pelaporan.

4. Jika biaya akad dibebankan pemilik obyek sewa maka biaya dialokasikan secara konsisten dengan alokasi pendapatan ijarah atau ijarah muntahia bit-tamlik selama masa akad.

5. Pengakuan biaya perbaikan obyek sewa adalah sebagai berikut:

a. Biaya perbaikan tidak rutin obyek sewa diakui pada saa terjadinya.

b. Jika penyewa melakukan perbaikan rutin obyek sewa dengan persetujuan pemilik obyek sewa maka biaya tersebut dibebankan kepada pemilik obek sewa dan diakui sebagai beban pada periode terjadinya perbaikan tersebut.

${ }^{37}$ Faqih Nabhan. 2006. Pengantar Akuntansi Bank Syariah: Implementasi PSAK No. 59 dan PAPSI 2003. Salatiga: STAIN Salatiga Press. c. Dalam ijarah muntahia bit-tamlik melalui penjualan secara bertahap biaya perbaikan obyek sewa yang dimaksud dalam huruf (a) dan (b) ditanggung pemilik obyek sewa maupun penyewa sebanding dengan bagian kepemilikan masing-masing.

6. Perpindahan hak milik obyek sewa dalam ijarah muntahia bit-tamlik melalui hibah diakui pada saat seluruh pembayaran sewa telah diselesaikan dan obyek sewa yang telah diserahkan kepada penyewa. Obyek sewa dikeluarkan dari aktiva pemilik obyek sewa pada saat terjadinya perpindahan hak milik obyek sewa.

7. Perpindahan hak milik obyek sewa dalam ijarah muntahia bit-tamlik melalui penjualan obyek sewa dengan harga sebesar sisa cicilan sewa sebelum berakhirnya masa sewa diakui pada saat penyewa membeli obyek sewa. Pemilik obyek sewa mengakui keuntungan atau kerugian atas penjualan tersebut sebesar selisih antara harga jual dan nilai buku bersih.

8. Pengakuan pelepasan obyek sewa dalam ijarah muntahia bit-tamlik melalui pembayaran sekadarnya adalah bagian berikut:

a. Perpindahan hak milik obyek sewa diakui jika seluruh pembayaran sewa telah diselesaikan dan penyewa membeli obyek sewa dari pemilik obyek sewa.

b. Obyek sewa dikeluarkan dari aktiva pemilik obyek sewa pada saat terjadinya perpindahan hak milik obyek sewa.

c. Jika penyewa berjanji untuk membeli obyek sewa tetapi kemudian memutuskan untuk tidak melakukan dan nilai wajar obyek sewa ternyata lebih rendah dari nilai bukunya, maka selisihnya 
diakui sebagai piutang pemilik obyek sewa pada penyewa.

d. Jika penyewa tidak berjanji untuk membeli obyek sewa dan memutuskan untuk tidak melakukannya, maka obyek sewa dinilai sebesar nilai wajar atau nilai buku mana yang lebih rendah. Jika nilai wajar obyek sewa tersebut lebih rendah dari nilai buku, maka selisihnya diakui sebagai kerugian pada periode berjalan.

9. Pengakuan pelepasan obyek sewa dalam ijarah muntahia bit-tamlik melalui penjualan obyek sewa secar bertahap adalah sebagai berikut:

a. Perpindaha hak milik sebagian obyek sewa diakui jika seluruh pembayaran sewa telah diselesaikan dan penyewa memberi sebagian obyek sewa dari pemilik obyek sewa.

b. Nilai buku bagian obyek sewa yang telah dijual dikeluarkan dari aktiva pemilik obyek sewa pada saat terjadinya perpindahan hak milik bagian obyek sewa.

c. Pemilik obyek sewa mengakui keuntungan atau kerugian sebesar selisih antara harga jual dan nilai buku atas bagian obyek sewa ag telah dijual.

d. Jika penyewa tidak melakukan pembelian atas obyek sewa yang tersisa maka perlakukan akuntansinya sesuai dengan ketentuan nomor 8 huruf c dan d.

10. Dalam ijarah muntahia bit-tamlik jika obyek sewa mengaami penurunan nilai permanen sebelum perpindahan hak milik kepada penyewa dan penurunan nilai tersebut timbul bukan akibat tindakan penyewa atau kelalaiannya, serat jumlah cicilan ijarah yang sudah dibayar melebihi nilai sewa yang wajar, maka selisih antara keduanya diakui sebagai kewajiban kepada penyewa dan dibebankan sebagai kerugian keduanya pada periode terjadinya penurunan nilai.

11. Jika asabah menjual aktiva kepada bank dan menyewakan kembali, maka perlakuan akuntansi bank sebagai pemilik obyek sewa diterapkan.

Bank dapat juga berfungsi sebagai pihak yang menyewa, kemudian menyewakan obyek sewa yang telah disewa bank kepada pihak lain. Apabila bank sebagai pihak penyewa, maka ketentuan akad ijarah dan ijarah muntahia bit-tamlik sebagaimana diatur dalam PSAK 59 adaah sebagai berikut: ${ }^{38}$

1. Beban ijarah dan ijarah muntahia bittamlik diakui secara proporsional selama akad.

2. Jika biaya akad menjadi beban penyewa maka biaya tersebut dialokasikan secara konsisten dengan ijarah atau ijarah muntahia bit-tamlik selama masa akad.

3. Jika biaya pemeliharaan rutin dan operasi obyek sewa berdasarkan akad menjadi beban penyewa maka biaya tersebut diakui sebagai beban pada saat terjadinya. Biaya pemeliharaan rutin dan operasi dalam ijarah muntahia bittamlik melalui penjualan obyek sewa secara bertahap akan meningkat secara progresif sejalan dengan peningkatan kepemilikan obyek sewa.

4. Perpindahan hak milik obyek sewa dalam ijarah muntahia bit-tamlik melalui hibah diakui pada saat seluruh pembayaran sewa ijarah telah diselesaikan dan obyek sewa telah diterima penyewa. Obyek sewa yang diterima diakui sebagai aktiva penyewa sebesar nilai wajar pada saat terjadinya.

\footnotetext{
${ }^{38}$ Baca lebih lanjut dalam Fiqih Nabhan. 2006. Pengantar Akuntansi bank Syariah: Implementasi PSAK No. 59 dan PAPSI 2003. Salatiga: STAIN Salatiga Press.
} 
Penerimaan obyek sewa tersebutdi sisi lain akan menambah:

a. Saldo laba, jika sumber pendana berasal dari modal bank.

b. Dana investasi tidak terikat, jika sumber pendana berasal dari simpanan pihak ketiga.

c. Saldo laba dan dana investasi tidak terikat secara proporsional, jika sumber pendanaan berasal dari modal bank dan dan simpanan pihak ketiga.

5. Perpindahan hak milik obyek sewa dalam ijarah muntahia bit-tamlik melalui pembelian obyek sewa dengan harga sebesar cicilan sewa sebelum berakhirnya masa sewa diakui pada saat penyewa membeli obyek sewa. Penyewa mengakui obyek sewa yang diterima diakui sebagai aktiva penyewa sebesar kas yang dibayarkan.

6. Pengakuan penerimaan obyek sewa dalam ijarah muntahia bit-tamlik melalui pembayaran sekedarnya sebagi berikut:

a. Perpindahan hak milik obyek sewa diakui jika seluruh pembayaran sewa ijarah telah diselesaikan dan penyewa membeli obyek sewa dari pemilik obyek sewa.

b. Obyek sewa yang diterima diakui sebagai aktiva penyewa sebesar kas.

7. Pengakuan penerimaan obyek sewa dalam ijarah muntahia bit-tamlik melalui pembeli obyek sewa secara bertahap adalah sebagai berikut:

a. Perpindahan hak milik sebagian obyek sewa diakui jika seluruh pembayaran sewa diselesaikan dan penyewa membeli sebagai obyek sewa dari pemilik obyek sewa.

b. Bagian obyek sewa yang diterima diakui sebagai aktiva penyewa sebesar perolehan.
8. Obyek sewa yang dibeli oleh penyewa yang disusutkan sesuai dengan kebijakan penyusutan.

9. Jika obyek sewa mengalami penurunan nilai permanent sebelum perpindahan hak milik kepada penyewa dan penurunan nilai tersebut timbul bukan akibat tindakan penyewa atau kelalaiannya, serta jumlah cicilan sewa yang sudah dibayarkan melebihi nilai sewa wajar, maka selisih antara keduanya (jumlah yang sudah dibayar penyewa untuk tujuan pembelian aktiva tersebut dan nilai sewa wajarnya) Diakui sebagai piutang jatuh tempo penyewa kepada pemilik sewa dan mengoreksi beban ijarah muntahia bit-tamlik.

10. jika bank menjual aktiva kepada nasabah dan menyewanya kembali, maka perlakuan akuntansi bank sebagai penyewa diterapkan sebagai berikut:

a. Keuntungan atau kerugian penjualan aktiva diakui bank pada saat terjadinya transaksi penjualan jika penyewaan kembali dilakukan secara ijarah.

b. Keuntungan atau kerugian penjualan aktiva dialokasikan sebagai penyesuaian terhadap beban ijarah selama masa akad jika penyewaan kembali dilakukan secara ijarah muntahia bit-tamlik.

Pemilik obyek sewa dapat meminta penyewa menyerahkan jaminan atas ijarah untuk menghindari resiko kerugian. Jumlah, ukuran, dan jenis obyek sewa harus jelas diketahui dan tercantum dalam akad. Perbaikan dan pemeliharaan atas obyek sewa yang dilakukan oleh penyewa, dapat bersifat perawatan rutin dan perbaikan yang bersifat tidak rutin. Dalam ijarah dan ijarah muntahia bit-tamlik, hak pemilikan obyek sewa masih menjadi milik pemilik obyek sewa, bukan penyewa. Sehingga perbaikan dan pemeliharaan obyek sewa sebenarnya masih menjadi 
tanggungan pemilik obyek sewa. Perawatan yang rutin dilakukan oleh penyewa -dengan persetujuan pemilik obyek- dapat dibebankan kepada pemilik obyek sewa. Perbaikan yang dilakukan karena kerusakan obyek sewa yang disebabkan oleh kesalahan penyewa tidak dapat dibebankan pada pemilik obyek sewa. Apabila terjadi perpindahan hak milik obyek sewa kepada penyewa dalam ijarah dan ijarah muntahia bit-tamlik dapat dilakukan dengan hibah, penjualan sebelum akad berakhir sebesar harga yang sebanding dengan sisa cicilan sewa, penjualan pada akhir masa sewa dengan pembayaran tertentu yang disepakati pada awal akad, dan penjualan bertahap sebesar harga yang disepakati dalam akad

\section{E. Penutup}

Kehadiran leasing telah menciptakan wahana baru untuk pengembangan pambiayaan investasi bagi dunia usaha, baik usaha kecil, menengah maupun besar. Adanya jasa leasing, pengusaha dapat melakukan perluasan produksi dan penambahan barang modal dengan cepat. Kebutuhan terhadap produk pembiayaan dengan sistem leasing ini pada dasarnya telah dirasakan sejak awal berdirinya bankbank islam, karena dapat melayani kebutuhan nasabah untuk memiliki barang, bukan jasa. Bagi perbankan syariah, produk leasing sangat dibutuhkan masyarakat untuk menopang ekonomi lemah, karena mampu berpartisipasi meningkatkan dan memberdayakan perekonomian yang berwujud dalam: (1) penciptaan iklim kondusif bagi masyarakat untuk berkembang, (2) peningkatan kemampuan masyarakat melalui pengembangan kelembagaan dan (3) menciptakan kemitraan yang saling menguntungkan. Pembiayaan dengan sistem leasing juga sangat menarik karena tidak dituntut dengan barang jaminan yang memberatkan serta adanya opsi yang memungkinkan untuk memiliki barang di akhir periode sewa atau mengembalikannya. Untuk mengindari sistem bunga, maka istilah yang dipakai bank syariah adalah ijarah muntahia bittamlik meskipun dalam operasionalnya memiliki kesamaan dengan leasing.

\section{DAFTAR PUSTAKA}

Afzalurrahman. (1995). Doktrin Ekonomi Islam, terj. Cet. I. Nastangin Yogyakarta: Yayasan Dana Bhakti Wakaf.

Ahmad, A. (1987). Leasing di Indonesia. Jakarta: Ghalia Indonesia.

An Nabhani, T. (1996). Membangun Sistem Ekonomi Alternatif Prespektif Islam. Surabaya: Risalah Gusti.

Ash Shiddiqi, N. (1986). Muslim Ekonomic Thingking, ter, Pemikiran Ekonomi Islam. Jakarta: LIPPM.

Baker, C. R (1981). Lease Financing: A Practical. Canada: John Wiley \& Sons, Inc.

Chapra, M. U. (1997) Towerds a Just Monetary System, Ter. Lukman Hakim). Al qur'an: menuju Sistem Moneter yang adil. Yogyakarta: Dana Bhakti.

Clark, T. (1985). Leasing Finance. London: Euromoney Publications.

Kahf, M. (n.d). Ekonomi Islam: Telaah Analitik terhadap Fungsi SIstem Ekonomi Islam. Yogyakarta: Pustaka Pelajar 1995.

Karim, A. (n.d) Ekonomi Islam: Suatu Tinjauan Kontemporer. Jakarta: Gema Insani Press, 2001.

Karim, M. R. (n.d). Berbagai Aspek Ekonomi Islam. Yogyakarta: Tiara Wacana 1992.

Komar, A. (1989). Serba Serbi Leasing, Bandung: Ikatan Notaris.

Lubis, S. K. (n.d). Hukum Ekonomi Islam. Jakarta: Sinar Grafika, 2000. 
M Yahya Harapah, I. d.-s (1991). Mimbar Hukum, Aktualisasi Hukum Islam, No 3 Thn II 1991.

Manna, M. A. (n.d). Islamic Ekonomic: Theory and Practice, Ter. M.
Nastangin, Teori dan Praktek Ekonomi Islam. Yogyakarta: Dana Bhakti Wakaf 1997. 
Sistem Pembiayaan Leasing Di Perbankan Syariah

Rausyan Fikr. Vol. 16 No. 2 September 2020. ISSN. 1979-0074 e-ISSN. $9772580594187 \mid 62$ 